Applied Informatics DIVAI-2016. (Slovakia, Štúrovo, May 2 - 4, 2016) (eds: Milan Turčáni, Zoltán Balogh, Michal Munk, L’ubomír Benko), Štúrovo: Wolters Kluwer, pp. 225-235.

4. Iljchenko O. V. (2012). Vykorystannja web-kvestiv u havchaljno-vykhovnomu procesi [The use of web-quests in educational process]. Osvita.ua [Education.ua] (electronic journal), Retrieved from: http://osvita.ua/school/lessons_summary/proftech/32834/(accessed 21 September 2019).

5. Matat, D. (2014). Novi tekhnologiji:veb-kvest [New technologies: web quest]. Education of Ukraine, vol. 23, pp. 10-11.

6. WebQuest.org. 2008. Available at: http://webquest.org/index.php (accessed 21 September 2019).

\title{
THEORETICAL APPROACHES TO NARRATIVE EMPATHY
}

\author{
Lyudmyla Lutsenko ${ }^{1}$ \\ Iryna Zorenko ${ }^{2}$
}

DOI: https://doi.org/10.30525/978-9934-588-11-2_43

Apart from philosophy and psychology the empathy concept has become widely used in politics, business and education. In the common lexicon it is generally understood as the capacity people have to fully comprehend the minds of others as if they were their own, whereas in academic discourse it is traditionally represented by as many as eight different meanings: «1. Knowing another person's internal state; including thoughts and feelings; 2. Adopting the posture or matching the neural responses of an observed other; 3. Coming to feel as another person feels; 4. Intuiting or projecting oneself into another's situation; 5. Imagining how another is thinking and feeling; 6. Imagining how one would think and feel in the other's place; 7. Feeling distress at witnessing another's person's suffering; 8. Feeling for another person who is suffering (empathic concern)» $[1$, p. 4-9]. On the one hand, such a variety of nuances in understanding empathy causes the problem of giving its clear, concise and unanimous definition, but at the same time it promotes an active academic interest in further exploring the empathy concept.

Translated from Greek empatheia «passion, state of emotion» and pathos «feeling»), the word «empathy» first appeared as Einfühlung in German philosophy and was associated with a number of aesthetics theorists who played a significant role in its elaboration: Johann Herbart (1776-1841) Johann Gottfried Herder (1744-1803), Karl Kostlin (1819-1894), Novalis (1772-1801), Robert Vischer (1847-1933). However, it was Theodor Lipps (1851-1913) who adjusted this concept for use in psychology for the first time. Today empathy is primarily regarded as a psychological process of «feeling what the other person feels, understanding the other from a distance (telepathy), or more generally to understandingly engage in other people's lives» $[4$, p. 20].

\footnotetext{
${ }^{1}$ Kryvyy Rih State Pedagogical University, Ukraine

${ }^{2}$ Kryvyy Rih State Pedagogical University, Ukraine 
The introduction of the word Einfühlung into the English language is traditionally attributed to a German-trained psychologist E. Titchener (1867-1927) who translated Einfühlung as «empathy» in 1909, yet, by this time the British writer and aesthetics theorist Vernon Lee (Violet Paget) had already used this term in a lecture given in London in 1895.

The idea that empathy has significance and contributes to creating a discourse which is capable of guiding the reader's feelings in the narrative occurs frequently in the twenty-first century research papers, however, the most detailed theoretical grounds in this respect have been recently developed by Suzanne Keen. In her book Narrative Form (2015) she defines narrative empathy as «the sharing of feeling and perspective-taking induced by reading, viewing, hearing, or imagining narratives of another's situation and condition» [3, p. 155] and singles out some of the narratological categories which are extensively employed $b$ authors with a view to making an emotional impact on the reader, and include actants, narrative situation, matters of pace and duration, settings.

Depending on the addressee-orientated perspective, the researcher introduces the notion of strategic empathy with the help of which authors attempt to direct an emotional transaction through a fictional work aimed at a particular audience, not necessarily including every reader of the text. Keen identifies such types of strategic narrative empathy as bounded, ambassadorial and broadcast, and claims that «bounded strategic empathy operates with an in-group, stemming from experiences of mutuality and leading to feeling with familiar others»; ambassadorial strategic empathy «addresses chosen others with the aim of cultivating their empathy for the in-group, often to a specific end», broadcast strategic empathy "calls upon every reader to feel with the members of a group, by emphasizing common vulnerabilities and hopes through universalizing representations» [2, p. 224].

The concepts suggested by Suzanne Keen enable researchers to detail the questions about empathy that philosophers, psychologists and literary critics pursue as well as further explore the representation of empathy in literature, and investigate specifically what empathy invoked by novels do to readers and for readers.

\section{References:}

1. Batson, C. D. (2009). These things called empathy: Eight related but distinct phenomena. In J. Decety \& W. Ickes (Eds.), Social neuroscience. The social neuroscience of empathy (pp. 3-15). Cambridge, MA, US: MIT Press.

2. Keen, S. (2006). A Theory of Narrative Empathy. Narrative. Vol. 14(3), pp. 207-236.

3. Keen, S. (2015). Narrative Form. London : Palgrave Macmillan, 161 p.

4. Manen, M. (2008). Pedagogical sensitivity and teachers practical knowing in-action. Peking University Education Review. Vol. 1, pp. 2-20. 